УДК 339.9:334.758.6+334.758.2(316.423.3)

DOI: https://doi.org/10.37320/2415-3583/8.4

Роспопчук T.M.

бакалавр міжнародної економіки, Київський політехнічний інститут імені Ігоря Сікорського ORCID: https://orcid.org/0000-0002-6743-2508

Войтко С.В.

доктор економічних наук, професор, Київський політехнічний інститут імені Ігоря Сікорського ORCID: https://orcid.org/0000-0002-2488-3210

\title{
ІНВЕРСІЯ ЗАСАД ЗЛИТТЯ І ПОГЛИНАННЯ В УМОВАХ INDUSTRY 4.0
}

У статті розглянуто понятійний апарат Industry 4.0. Проаналізовано надбання промислових революиій від першої по третю. Описано поняття "Industry 4.0” та основні технології. Наведено світовий рейтинг капіталізачї̈ компаній. Зроблено висновки стосовно зміни лідерів у иьому рейтингу. Зазначено обсяги капіталізації окремих компаній за даними останніх 2 років. Охарактеризовано прочеси злиття й поглинання у зрізі забезпечення гнучкості бізнесу та конкурентоспроможності в Industry 4.0. Здійснено оцінювання викликів ринку з огляду на інноваиії, постійних технологічних нововведень, вимог до послуг $і$ товарів. Зазначено те, як саме М\&А може стати інструментом для забезпечення стійкого зростання на ринку. Порівняно тендениії періодів 2000-2010 років і 2010-2019 років за показником кількості укладених угод злиття й поглинання. Визначено, щчо найактивнішими були телекомунікачійні, харчові та фармацевтичні компанії. Розглянуто діяльність китайських корпорацій. Зазначено те, в яких сферах умови ринку змінюються швидше. Наведено засади оцінювання конкурентоспроможності компанії. Доведено, щзо злиття й поглинання використовуються для залучення нових технологій, синергії витрат, охоплення все більших територій, скорочення витрат на виробниитво та доставку до споживачів. Виявлено тендениії щзодо переважання угод злиття над угодами поглинання. Наведено особливості використання технологій blockchain та хмарних технологій у функиіонуванні глобальних компаній. Виявлено, щчо Industry 4.0 сприяє тому, щцо компанї втрачають поняття локалізаиії. Прикладом компанії, на яку не впливає її розташування та потреба в ресурсах, $\epsilon$ “Атаzоп”, яка надає послуги хмарних сховиш і працює над розробленням та вдосконаленням штучного інтелекту. Сформульовано необхідні дії для успішного функціонування компанії в умовах Industry 4.0. Основними завданнями компаній є планування стратегічних змін, постановка довгострокових ціілей, розроблення планів і перспектив розвитку.

Ключові слова: Індустрія 4.0, blockchain, роботизація, злиття та поглинання.

Постановка проблеми. Розглянемо детально, що таке Industry 4.0, а також іï особливості. Варто зазначити, що існують два поняття, такі як «Четверта промислова революція» та "Industry 4.0", Між цими поняттями є деякі відмінності.

Перше поняття містить зміни та технологічний прорив саме у сфері промислового виробництва. “Industry" можна перекластиз англійської не тільки як промисловість, але й як галузь, тому це поняття може застосовуватися в усіх сферах, а не тільки у промисловості. Четвертій промисловій революції передували три інші. Завдяки Третій промисловій революції здійснено комп'ютеризацію виробництва. Четверта революція - це вже більше про повну автоматизацію виробництва, аналіз даних в умовах реального часу та можливість передбачення проблем, що можуть постати [1].

Аналіз останніх досліджень i публікацій. Технології, що з'явилися завдяки Industry 4.0, дають можливість передбачати можливі зміни та усувати проблеми ще до того, як вони стануть критичними. Грунтовне дослідження Industry 4.0 здійснив Клаус Шваб, що $є$ засновником i виконавчою головою Всесвітнього економічного форуму, у статті “The Fourth Industrial Revolution: what it means, how to respond". Технологіï Industry 4.0 дають змогу ефективно організовувати виробництво, задовольняти потреби споживачів більш швидко та точно. Завдяки розвитку кібербезпеки, blockchain та великих баз даних компанії стають більш гнучкими та швидше пристосовуються до змін. Вони можуть точніше прогнозувати та передбачити зміни майбутніх періодів, ухвалювати рішення відповідно до них. Нагальною проблемою постає злиття й поглинання Mergers and Acquisitions (M\&A).

Мета статті полягає у з'ясуванні того, як саме змінюються форми M\&A, як це відображається на функціонуванні компаній; аналізі тенденцій щодо укладання угод M\&A; виявленні того, як впливає Industry 4.0 на діяльність компаній.

Під час дослідження використано аналіз наявних тенденцій та можливостей, абстрактнологічний аналіз, порівняння компаній для виділення характерних рис компаній, що укладають угоди М\&A.

Виклад основного матеріалу. 3 розвитком штучного інтелекту, діджиталізації та Інтернету речей спостерігаються зміни у світовому рейтингу капіталізації компаній. Раніше перші 
місця цього рейтингу посідали нафтові та газові компанії. Проаналізувавши рейтинг "Global Top 100 Companies 2019”, що був опублікований компанією "РwC", бачимо, що перші місця в рейтингу посідають інформаційно-телекомунікаційні компанії. Першу шістку складають компанії зі США, такі як "Microsoft" (\$905 млрд.), “Apple" (\$896 млрд.), “Amazon” (\$875 млрд.), “Alphabet" (\$817 млрд.), "Berkshire Hathaway” (\$494 млрд.), “Facebook" (\$476 млрд.). Далі йдуть китайські “Alibaba” (\$472 млрд.) i “Tencent” (\$438 млрд). Замикають десятку також американці, а саме "Johnson\&Jonhson" (\$372 млрд.) i "Exxon Mobil" (\$342 млрд.) (рис. 1). Тільки дві 3 цих компаній займаються іншими напрямами діяльності, що не стосуються інформаційних технологій [2].

Ринкова капіталізація 100 найбільших публічних компаній світу за 12 місяців (квітень 2018 року - березень 2019 року) зросла на 5\%, досягнувши рекордної позначки у \$21 трлн. Крупні транснаціональні корпорації використовують злиття й поглинання для того, щоби захопити більшу частку ринку та висувати свою продукцію на нові ринки, спонукати диверсифікацію виробництва для більшого задоволення потреб споживачів.

Злиття й поглинання забезпечують бізнесу гнучкість і дають можливість залишатися конкурентоспроможними як сьогодні, так і в дов- гостроковій перспективі. Злиття й поглинання характерні для всіх сфер діяльності. Виробники коригують свої портфелі та заключають нові угоди, щоби пристосуватися до нових ринкових реалій. Наприклад, можна розглянути сферу легкої промисловості та роздрібної торгівлі.

Так, сфера легкої промисловості та роздрібної торгівлі особливо гостро стикається 3 такими викликами ринку, як інновації, нові учасники ринку, аналізування й консолідація даних. Постійні технологічні нововведення провокують розвиток компаній, а також злиття й поглинання їх більш сильними гравцями на ринку. Конкуренція у цій сфері швидко зростає, як і потреби споживачів. Вимоги до послуг і товарів, що пропонуються, стають вищими, тому компанії не можуть у такому темпі самостійно задовольняти їх повністю. Проблеми та можливості такого середовища потребують гнучкості, яку можуть забезпечити угоди злиття й поглинання. На цьому етапі виникає інверсія засад злиттів і поглинань компаній. Компанії прагнуть максимально відповідати запитам клієнтів і виправдовувати їх сподівання, для чого вони об'єднуються та створюють стратегічні партнерства.

Слід зауважити, що угоди злиття й поглинання здійснюються для того, щоб отримати нові технології. Крім того, компанія має можливість отримати науково-практичні результати вна-

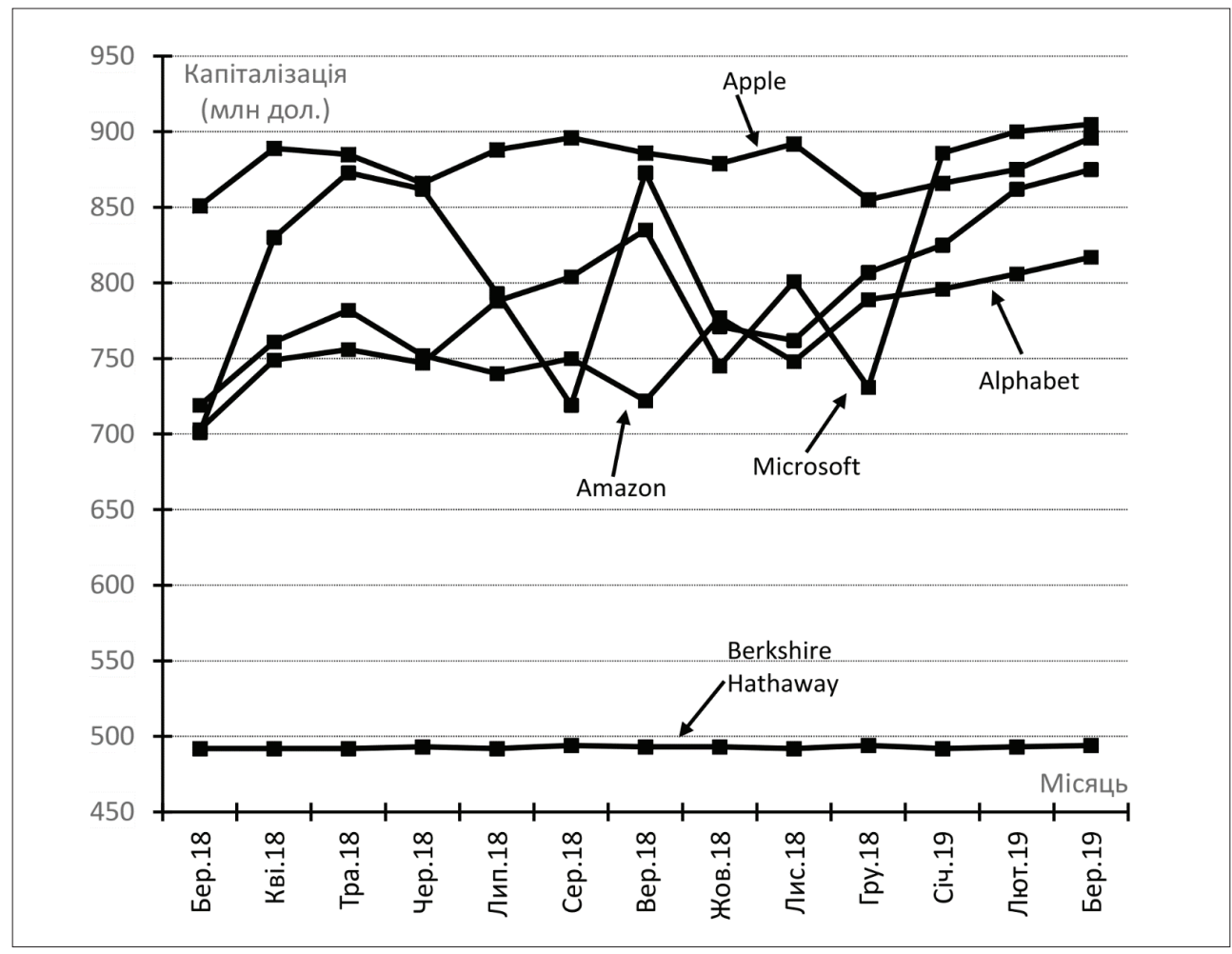

Рисунок 1 - Обсяги капіталізації компаній за березень 2018 року - березень 2019 року

Джерело: складено авторами за даними джерела [2] 
слідок або власних досліджень, або придбання інтелектуальної власності із зовнішніх джерел як об'єктів права.

Для кращого розуміння ключових тенденцій, що впливають на умови здійснення угод злиття й поглинання у 2018 році, компанією "KPMG" опубліковано звіт «Нові можливості зростання» [3], щоби сприяти розумінню того, де саме є такі можливості. Матеріал звіту ілюструє те, як саме "M\&A" може стати інструментом для забезпечення стійкого зростання на ринку. У звіті наводиться інформація про те, чому саме злиття й поглинання стають ключовим рішенням деяких проблем підприємства.

Порівнюючи тенденції періодів 2000-2010 років і 2010-2019 років, спостерігаємо різке зростання кількості укладених угод злиття й поглинання. Якщо в першому періоді таких угод було 10, то в другому періоді станом на 2019 рік вже укладено 54 угоди.

Найбільші угоди були укладені між:

- "Verizon Communications" та "Verizon Wireless", тобто телекомунікаційними компаніями, які надають послуги бездротового зв'язку, цифрові носії та Інтернет (угоду було завершено у 2014 році, коли "Verizon" придбав 45\% акцій "Verizon Wireless", що належить "Vodafone", за $\$ 130$ млрд., це була третя найбільша угода в історії діяльності компаніі);

- "Dow Chemical" та "DuPont", тобто хімічними корпораціями, які виробляють пластмаси, хімікати та сільськогосподарську продукцію (угода була укладена у 2015 році, іiї вартість становила \$130 млрд.);

- "United Technologies" та "Reytheon" (угода укладена у 2019 році в галузі аерокосмічних технологій та будівництва, об'єднана компанія оцінюється в \$100 млрд., а після запланованих виплат буде другою за величиною у світі аерокосмічною та оборонною компанією).

Більшість угод укладалась телекомунікаційними, харчовими та фармацевтичними компаніями. Зростання укладених угод спровоковане змінами у світовій економіці та суттєвою конкуренцією між компаніями. Такі угоди відіграють важливу роль в інтеграції національних економік. Найбільше угод злиттів і поглинань укладено між компаніями США, Німеччини, Великобританії та Ірландії.

Варто розглянути діяльність китайських корпорацій. У Китаї всі крупні корпорації перебувають у державній власності, а на державному рівні там укладаються угоди об'єднань компаній. Впродовж 2015-2018 років у Китаї було укладено 6 угод про злиття, всі вони стосувались енергетичної та промислової сфер. Завдяки укладеній у серпні 2017 року угоді "SASAC" (State-owned Assets Supervision and Administration Commission) оголосила, що корпорація "China Guodian” (один 3 найбільших виробників вугілля у Китаї) та "Shenhua Group" будуть реструктуризовані, i "Shenhua Group" перетвориться на корпорацію "China Energy Investment Corporation". У такий спосіб вона стала найбільшою енергетичною компанією за встановленими потужностями.

У зв'язку з останніми злиттями й поглинаннями корпорації всіх розмірів продовжують оцінювати свою конкурентоспроможність. Існують різні види оцінювання конкурентоспроможності компанії. Для ТНК доцільним $\epsilon$ використання одразу декількох методів, включаючи портфельні (метод ADL, модель Hofer тощо) й методи, які характеризують фінансово-економічну діяльність підприємства, зокрема аналіз ефективності менеджменту компанії [4].

Перед топ-менеджерами стоїть важливе завдання проаналізувати значну кількість факторів i ризиків, що на них впливають, оцінити всі переваги й недоліки укладання угод, а також наслідки, які це матиме для компаній, тому що далеко не всі укладені угоди про злиття чи поглинання $є$ успішними, як і не всі угоди вдається довести до кінця. Через невдалі угоди компанія може понести зайві втрати. Так, була скасована міжнародна угода між американською фармацевтичною компанією "Pfizer" та ірландською "Allergan Plc" через зміни в податковому законодавстві США. Вартість угоди становила $\$ 160$ млрд.

Злиття й поглинання використовуються для синергії витрат, охоплення все більших територій. Через об'єднання компанії можуть скорочувати свої витрати на виробництво та доставку до споживачів. Вони оптимізують свої видатки та пропонують вищу якість за меншу вартість.

Останніми роками загальна кількість укладених угод про поглинання між компаніями скоротилась. Раніше відбувалося більше таких угод. Великі гравці на ринку намагалися таким чином усувати конкурентів і збільшувати свою ринкову частку. Зараз компанії укладають угоди злиття, тобто для компаній вигідніше утворювати альянси та організовувати спільну діяльність.

Під впливом Industry 4.0 та в умовах цифрової глобалізації реальне використання злиттів і поглинань дещо змінюється. Ефективніше створювати глобальні компанії. У такий спосіб компанії обмінюються новими технологіями та поширюють свою діяльність. Глобальні компанії охоплюють більшу частку ринку та диверсифікують діяльність. Завдяки технології blockchain та хмарним технологіям функціонування глобальних компаній може бути більш прибутковим. Вигоди від зменшення рівня складності та вартості транзакцій, а також підвищення прозорості та контролю над шахрайством можуть бути використані компаніями за допомогою відповідної 
архітектури blockchain. Економічні стимули для залучення ціннісних можливостей спонукають членів організацій використовувати blockchain, а не наздоганяти його. Приватний blockchain дає змогу підприємствам витягувати комерційну цінність 3 реалізації технології blockchain. Домінуючі гравці на ринку можуть зберегти свої позиції або об'єднати зусилля 3 іншими гравцями галузі, щоби здобути та поділити вигоди. Учасники можуть отримати вигоди безпечного обміну даними під час автоматичного контролю того, що ділиться, 3 ким і коли.

Для всіх компаній дозволені блок-ланцюги дають можливість розробити виразні комерційні пропозиції, які починаються 3 малого експерименту, а потім їх масштабувати. Поточні випадки використання включають австралійську біржу цінних паперів, для якої розгортається blockchain, тобто система клірингу акцій, щоби зменшити час на укладання та обговорення договорів між офісами посередників. "IBM" та "Maersk Line" (найбільша у світі судноплавна компанія) створюють спільне підприємство з виведення на ринок торгової платформи на основі blockchain. Метою платформи $\epsilon$ забезпечення користувачів та учасників, що беруть участь у глобальних операціях 3 доставки, безпечним обміном даними ланцюгів постачань у реальному часі та оформленням документів. Технологія blockchain може вирішити необхідність організації, відповідальної за управління, зберігання й фінансування бази даних. Технології blockchain також активно розробляє та впроваджує компанія “Тoyota” через свій науководослідний інститут. Разом з чотирма партнерами розроблено "Blockchain Mobility Consortium", щоби зосередитись на blockchain- рішеннях для критичних прискорювачів автономних транспортних засобів, таких як обмін даними, транзакції між компаніями.

Компанії - лідери за рівнем капіталізації розширюють напрями діяльності через використання угод злиття й впровадження технологій, що відкрила Industry 4.0. При цьому компанії втрачають поняття локалізації. Вони не прив'язуються до країн базування. Для прикладу візьмемо компанію “Amazon". Ця компанія розпочала свою діяльність як інтернет-сервіс, а зараз $є$ однією 3 крупніших компаній за рівнем капіталізації у світі, у 2019 році обсяги ії прибутків перевищили прибутки "Microsoft". "Amazon" в умовах всезагального переходу на онлайн-платформи почала надавати послуги хмарних сховищ і працює над розробленням та вдосконаленням штучного інтелекту. На діяльність компанії не впливає іiі роз- ташування, адже через Інтернет вона охоплює практично всі країни світу, користувачі Інтернету мають доступ до неї. На "Amazon" не впливає потреба в ресурсах. У 2018 році компанія відкрила свій перший офлайновий магазин. 3 кожним роком компанія охоплює все більше сфер, диверсифікуючи свою діяльність. Для створення ефективної стратегії та досягнення цілей розвитку “Amazon" використовує угоди злиттів і поглинань. Зараз це одна з масштабніших корпорацій, яка й надалі продовжує зростати, тому для успішного функціонування компанії в умовах Industry 4.0 важливими $€$ планування стратегічних змін, постановка довгострокових цілей, розроблення планів і перспектив розвитку. Керівники мають розробляти глобальні стратегії усунення й подолання ризиків [5].

Висновки. Характерною рисою зміни засад злиттів і поглинань $€$ зміщення акценту на користь угод злиттів. Зазначимо, що за 2016-2019 роки змінилася структура бізнесу успішних компаній 3 високими рівнями капіталізації. Зараз перші позиції в цьому рейтингу займають інформаційно-телекомунікаційні компанії. Особливістю цих компаній $є$ те, що вони меншою мірою прив'язані до певної країни та ресурсів, оскільки постачання продуктів і послуг здійснюється через всесвітню мережу Інтернет. Це впливало на зміну понять злиття й поглинання для компаній. За результатами досліджень кількість угод поглинань скорочується, відбувається злиття компаній задля створення глобальних компаній та глобальної мережі.

Industry 4.0 значною мірою впливає на діяльність компаній, особливо транснаціональних. У них проводяться розроблення нових технологій, значні суми вкладаються в науково-дослідницькі центри. Зокрема, "Тoyota" через свій науководослідний інститут разом з чотирма партнерами розробила Blockchain Mobility Consortium для поширення технологіï blockchain.

Робота $є$ основою для подальшого поглибленого наукового дослідження впливу Industry 4.0 на розвиток ТНК та інших різновидів крупних компаній. Практична значущість роботи полягає в тому, що отримані результати, які стосуються інверсії засад злиття й поглинання в умовах Industry 4.0, можна використати для вибору галузі, у якій компанія може досягти вищого рівня капіталізації.

Перспективами подальших досліджень є аналізування угод злиттів і поглинань, укладених між закордонними та українськими компаніями; оцінювання потенціалу створення глобальної мережі ТНК на найближчі 10 років. 


\section{Список використаних джерел:}

1. What is Industry 4.0 - the Industrial Internet of Things (IIoT). Epicor. URL: https://www.epicor.com/en-us/resourcecenter/articles/what-is-industry-4-0 (дата звернення: 14.10.2019).

2. Global Top 100 Companies 2019. Pricewaterhouse Coopers. URL: https://pwc.to/2Ko44Zl (дата звернення: 14.10.2019).

3. Capturing new growth opportunities. KPMG. URL https://assets.kpmg/content/dam/kpmg/xx/pdf/2018/02/globalconsumer-retail-m-and-a-trends-2018.pdf (дата звернення: 14.10.2019).

4. Прохорова М.Е. Аналіз сучасних тенденцій розвитку міжнародних злиттів та поглинань. Актуальні проблеми міжнародних відносин. 2014. № 121 (2). С. 185-199. URL: http://nbuv.gov.ua/UJRN/apmv_2014_121\%282\%29_21 (дата звернення: 14.10.2019).

5. Войтко С.В. Управління проектами та стартапами в Індустрії 4.0. Київ, 2019. С. 85-89.

\section{References:}

1. Epicor. (2019), "What is Industry 4.0 - the Industrial Internet of Things (IIoT)", available at: https://www.epicor.com/ en-us/resource-center/articles/what-is-industry-4-0 (accessed: 14 Oct 2019).

2. PricewaterhouseCoopers. (2019), “Global Top 100 Companies 2019”, available at: https://pwc.to/2Ko44Z1 (accessed: 14 Oct 2019).

3. KPMG. (2018), "Capturing new growth opportunities", available at: https://assets.kpmg/content/dam/kpmg/xx/ pdf/2018/02/global-consumer-retail-m-and-a-trends-2018.pdf (accessed: 14 Oct 2019).

4. Prokhorova M.Ye. (2014), "Analysis of current trends in the development of international mergers and acquisitions", Actual problems of international relations, vol. 121 (2), pp. 185-199.

5. Voitko S.V. (2019), Upravleniye proyektami i startapami v industrii 4.0 [Project and Startup Management in Industry 4.0], Kyiv, Ukraine. pp. 85-89.

Rospopchuk Tetiana, Voitko Serhii National Technical University of Ukraine "Igor Sikorsky Kyiv Polytechnic Institute"

\section{INVERSION OF PRINCIPLES OF MERGERS AND ACQUISITIONS IN TERM OF INDUSTRY 4.0}

The concept apparatus Industry 4.0 is considered. The property of an industrial revolution, from the first to the third, is analyzed. Industry 4.0 concepts and basic technologies are described. The global rating of companies'capitalization is given. Conclusions have been made regarding the change in leaders in this rating. The volumes of capitalization of individual companies according to the data of the last 2 years are indicated. The merger and acquisition processes are characterized by cutting business flexibility and competitiveness in Industry 4.0. Market challenges have been assessed in the light of innovations, ongoing technological innovations, service, and product requirements. It is outlined how M\&A can be a tool for sustaining market growth. Compared to the trends of 2000-2010 and 2010-2019, the number of mergers and acquisitions concluded. It was determined that the most active were telecommunications, food and pharmaceutical companies. The activity of Chinese corporations is considered. In which areas the market conditions change faster. The principles of assessing the competitiveness of the company are given. Mergers and acquisitions have been proven to attract new technologies, cost synergies, expanding territories, and reduce production and delivery costs to consumers. Trends in the predominance of merger agreements over acquisitions have been identified. The features of the use of blockchain technology and cloud technologies in the functioning of global companies are presented. Industry 4.0 has been found to contribute to the fact that companies are losing the concept of localization. An example of a company that is unaffected by its location and resource requirements is Amazon, which provides cloud storage services and is working on developing and improving artificial intelligence. The necessary actions for the successful operation of the company in the conditions of Industry 4.0 are formulated. The main tasks of the companies are: planning strategic changes, setting long-term goals, developing plans and prospects.

Key words: Industry 4.0, blockchain, work, mergers and acquisitions.

JEL classification: F15, F23, L16, L25, O14. 